\title{
ELECTRICAL PROPERTIES CdO THIN FILMS PREPARED BY
}

\section{SPRAY PYROLYSIS.}

\section{Y. D. Tembhurkar}

Department of Physics, S. K. Porwal College Kamptee, Nagpur-441001 Corresponding author E-mail -y_dt@rediffmail.com.

\begin{abstract}
.
A CdO thin film was prepared using aqueous solutions of cadmium chloride by spray pyrolysis. The substrate temperature was $350{ }^{\circ} \mathrm{C}$. Thickness of the films was calculated by using Michelson-interferometer. Electrical resistivity calculated by Four-Probe method for the temperature range $300{ }^{\circ} \mathrm{K}$ to $600^{\circ} \mathrm{K}$. The two distinct regions corresponding to low and high temperature which indicates the presence of shallows and deep traps level were found.
\end{abstract}

Keywords. Spray pyrolysis, electrical properties, thin films.

\section{Introduction}

Semiconductor-liquid junction solar cells are of considerable interest for solar energy conversion because they are simple in construction and have the advantage of being used for both photovoltaic and chemical energy conversion $(1,2)$. But the problem is to find semiconductor electrode material which will be stable in an electrolyte inexpensive and simple for preparation. Cadmium oxide is a small band gap $(<2.5 \mathrm{eV})$ semiconductor to allow efficient utilization of solar spectrum .It has absorption coefficient (3) of the order of $104 \mathrm{~cm}$ 1.cadmium sulphide and cadmium selenide compound belongs to II-VI group and are used in the variety of semiconductor devices such as solar cells, transistors, photoconductor. The large band gap semiconductor electrode such as $\mathrm{TiO}_{2}, \mathrm{ZnO}$ etc offer the possibilities for studies of the energy parameter of fundamental charge transfer processes.

An attempt has been made discuss the electrical properties of $\mathrm{CdO}$ thin films prepared by spray pyrolysis method using cadmium chloride solutions at $350^{\circ} \mathrm{C}$. This method of preparing thin film is simple and inexpensive. Resistivity measurement was carried out on Four-probe method. Thickness of the films was calculated by Michelson- 
interferometer. Temperature of the substrate was measured by precalibrated thermocouple.

\section{Experimental Procedure}

Aqueous solution of cadmium chloride of $0.1 \mathrm{M}$ was used for spraying the films on hot glass substrate. Solution was prepared in double distilled water. The chemical used was of AR grade. Biological glass slides $1.3 \mathrm{~mm}$ thick were used as a substrate the spray rate was maintained as $3.5 \mathrm{ml} / \mathrm{min}$ by using compressor air machine.

\section{Resistivity Measurement}

The electrical resistivity of $\mathrm{CdO}$ thin films with temperature was studies in the temperature range $300^{\circ} \mathrm{K}$ to $600^{\circ} \mathrm{K}$ by plotting the graphs $\log \rho$ verses $1 / \mathrm{T}$. The plot obeyed the following relation $(5,6)$.

$\rho=\rho_{0} \exp \left(-\mathrm{E}_{\mathrm{a}} / \mathrm{kT}\right)$

where, $\rho$-Resistivity, $\rho_{0}$ - pre-exponential terms, $\mathrm{E}_{\mathrm{a}}$ is the activation energy, $\mathrm{k}$ - Boltzmann constant, $\mathrm{T}$ - absolute temperature.

The graph shows two distinct regions corresponding to low and high temperature regions i.e. temperature $300{ }^{\circ} \mathrm{K}$ to $480{ }^{\circ} \mathrm{K}$ and $480{ }^{\circ} \mathrm{K}$ to 600 ${ }^{0} \mathrm{~K}$. The two activation energies calculated from the slope of the plots .The activation

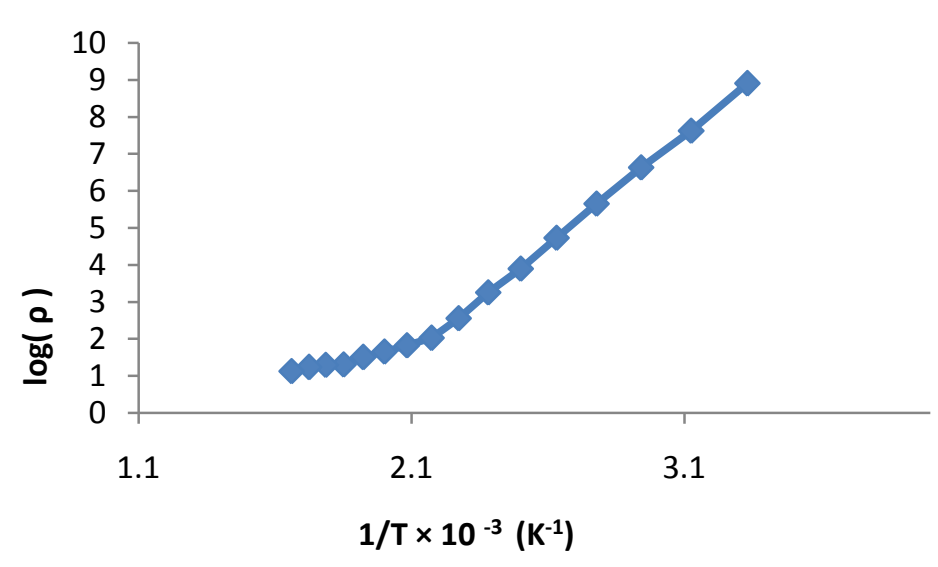

Fig.1 Variation of log $\rho$ verses $1 / T$ of as deposited thin films. 
Energies $0.06 \mathrm{eV}$ for the temperature 300 to $480{ }^{\circ} \mathrm{K}$ and $0.35 \mathrm{eV}$ for the temperature $480{ }^{\circ} \mathrm{K}$ to $600{ }^{\circ} \mathrm{K}$, which indicates the presence of shallow and deep traps levels. This result also agreed well with the result obtained by Lokhande et al (3).

\section{Conclusion}

The CdO thin films are prepared from the cadmium chloride solution by spray pyrolysis technique. The electrical properties of the films was studied. It has two region for the temperature $300{ }^{\circ} \mathrm{K}$ to $480{ }^{\circ} \mathrm{K}$ and 480 ${ }^{0} \mathrm{~K}$ to $600{ }^{\circ} \mathrm{K}$ which shows the presence of shallow and deep traps levels.

\section{Reference}

Shoonman J. Ber Bunsenges . (1982). Phys .chem. (Germany) 86, 660.

Kung H.K, Jarret H.S, Sleigth A W and Ferreti A. (1977). J. Appl. Phys (USA), 48, 2463.

Lokhande C.D, Bhat V.V and Dhumare S.S . (1992). J. Phys.D,25, 315.

Lokhande C.D and Gadave K.M. (1993). mater chem.Phys. 36, 119.

Tembhurkar Y. D.

Masse. G, (1984). J. Phys. chem. Solid, 45, 1091.

Miggliorato and J.L. Shar, (1975). J. Appl. Phys, 46, 1777

Fray A.F and Loyd.P, (1978). Procth Int. Conf.on thin films Loughborough, Sept11-15, Elsevier, Oxford, paper 215,P-29.. 